\title{
Composition and Working of the Sharia Supervisory Boards in Bahrain's Islamic Banks
}

\author{
Bhartesh Ramprakash Kasi ${ }^{1}$ \\ Najdat Mahmood ${ }^{2}$ (D)
}

'Head of Business Department, College of Business \& Financial Sciences, Royal University for Women, West Riffa Kingdom of Bahrain.

Email:bkasi@ruw.edu.bh

'Associate Professor, College of Business E Financial Sciences, Royal University for Women, West Riffa Kingdom of Bahrain.

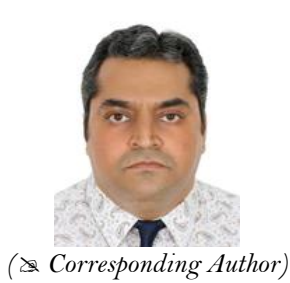

\section{Abstract}

The global Islamic finance industry has grown rapidly in the last ten years recording an average growth of over 10 percent and is expected to touch USD 3 trillion by 2020. The Gulf Cooperation Council Countries, Iran and Malaysia; have been central to the success story of the global Islamic finance industry accounting for 83 percent of the market size. Even though Islamic finance covers a wide range of financial service segments, 75 percent of the global Islamic financial assets are held by Islamic Banks, which explains the general notion of equating Islamic finance with Islamic banking. Islamic banking refers to a system of banking, which is consistent and in compliance with Islamic law, also known as Sharia. It is seen as an alternative to western-based banking in Islamic countries. Even though many Islamic countries have in place a Sharia supervisory and governance framework for Islamic banks, it has often been commented that these frameworks are inadequate when it comes to addressing the issues and challenges confronting Islamic banks today. Previous researchers have specifically identified issues concerning the membership and workings of the Sharia Boards as one of the major challenges confronting growth of Islamic banks. The purpose of this paper is to examine and comment on the constitution, composition and functioning of Sharia Boards within Islamic banks based in the Kingdom of Bahrain.

Keywords: Islamic banks, Islamic finance, Sharia board, Sharia supervisory board, Sharia scholar, Bahrain

JEL Classification: G2 1; G28; G29; E58.

Citation | Bhartesh Ramprakash Kasi; Najdat Mahmood (2019). Composition and Working of the Sharia Supervisory Boards in Bahrain's Islamic Banks. Economy, 6(2): 76-81.

History:

Received: 16 August 2019

Revised: 19 September 2019

Accepted: 22 October 2019

Licensed: This work is licensed under a Creative Commons Attribution 3.0 License (cc)

Publisher: Asian Online Journal Publishing Group
Acknowledgement: Both authors contributed to the conception and design of the study.

Funding: This study received no specific financial support.

Competing Interests: The authors declare that they have no conflict of interests.

Transparency: The authors confirm that the manuscript is an honest, accurate, and transparent account of the study was reported; that no vital features of the study have been omitted; and that any discrepancies from the features of the study have been omitte
study as planned have been explained.

Ethical: This study follows all ethical practices during writing.

\section{Contents}

1. Introduction

3. Research Approach and Methodology ......... 79

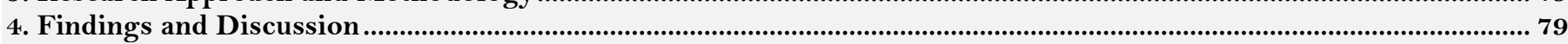

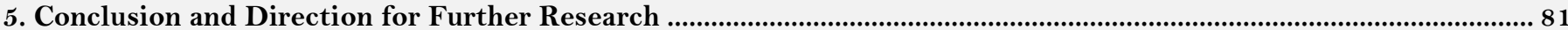

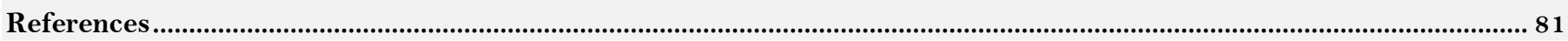




\section{Contribution of this paper to the literature}

This study contributes to the existing literature by examining and comment on the constitution, composition and functioning of Sharia Boards within Islamic banks based in the Kingdom of Bahrain.

\section{Introduction}

The global Islamic finance industry has grown rapidly in the last ten years recording an average growth of over 10\% (from USD 0.639 trillion during 2007 to USD 2.2 trillion by the end of 2016) and is expected to touch USD 3 trillion by 2020. The GCC (Gulf Cooperation Council) Countries, Iran and Malaysia; have been central to the growth story of the global Islamic finance industry accounting for $83 \%$ of the market size. Even though Islamic finance covers a wide range of financial service segments, $75 \%$ of the global Islamic financial assets are held by Islamic Banks, which explains the general notion of equating Islamic finance with Islamic banking. The other segments of Islamic finance industry includes the Sukuk (15\%), Islamic funds (4\%), Takaful (1\%) and microfinance (1\%) (GIFR, 2017).

The Kingdom of Bahrain is considered to be the leading Islamic financial market in the gulf and the MENA (Middle East and North Africa) region, ranking number 2 among the top 15 countries in the ICD-Thomson Reuters Islamic Finance Development Indicator (ICD Thomson Reuters, 2017). The Kingdom also hosts the region's largest concentration of Islamic financial institutions. According to the EDB (Bahrain Economic Development Board), there are 25 Islamic banks in Bahrain, accounting for more than $13 \%$ of the Kingdom's total banking assets and growing from USD 1.9 billion in 2000 to USD 25.7 billion by December 2016 (Bahrain, 2017).

In Islamic countries and in countries with large Muslim populations, Islamic Banking is increasingly seen as an alternative to conventional or western-based banking. Four factors in particular are seen as unique to Islamic banking (Imam and Kpodar, 2010).

- Prohibition of interest (Riba).

- Prohibition of maysir (games of chance) and of gharar (chance).

- Prohibition of haram (illegal) activities.

- Payment of part of bank profits to benefit society (zakat).

Islamic banking refers to a system of banking, which is consistent and in compliance with Islamic law, also known as Sharia (divine rules). Sharia compliant or adhering to sharia means observing strictly what is permissible (halal) or staying away from the prohibited (haram). In order to assure an Islamic bank's stakeholders that the Bank is doing its business in a sharia permissible manner, the services of religious boards comprising sharia scholars known as Sharia Boards are employed (Aziz, 2012; Grassa, 2013). The Sharia Supervisory Board, which is peculiar to Islamic banks is considered as the principal component of the Sharia governance framework (Hamza, 2013). A Sharia Supervisory Board exists in addition to the usual governance structures, but its functions are mainly to certify and monitor financial contracts, transactions, and activities of an Islamic bank on behalf of stakeholders and clients to ensure that they are compliant with the Sharia (Alman, 2012).

The risk of Sharia incompliance has serious consequence on the existence and development of the Islamic banks and the industry, thereby justifying the need for an effective sharia supervisory and governance framework.

Over the last two decades, attempts have been made in a number of countries to develop a sharia governance framework for Islamic banks, in line with standards and guidelines issued by two international standard setting agencies, the Accounting and Auditing Organization for Islamic Financial Institutions (AAOIFI), headquartered in Bahrain and the Islamic Financial Standard Board (IFSB), headquartered in Malaysia.

\section{Literature Review}

According to the IFSB, Sharia governance refers to a set of institutional and organizational arrangements through which an Islamic Financial Institution ensures that there is effective independent oversight of Sharia compliance over issuance of relevant Sharia pronouncements, dissemination of information and an internal Sharia compliance review (IFSB, 2009; Mizushima, 2014). In line with IFSB guidelines, the supervision and governance structure in Islamic Banks is expected to include a Sharia Supervisory Board (SSB), composed of qualified scholars in Fiqh al Muamalat appointed by shareholders and reporting to the board of directors, with the responsibility of certifying and monitoring financial contracts, transactions, and activities of a Islamic bank on behalf of stakeholders and clients to ensure that they are compliant with the Sharia; an internal Sharia review process, carried out by an independent department to monitor, evaluate and produce reports on sharia compliance; and; periodic Sharia reviews covering policies and transactions, which form the basis of the report of the Sharia Supervisory Board. (Mejia et al., 2014).

Garas and Pierce (2010) commenting on the sharia supervision in Islamic financial institutions (IFI), observed that it can assume different forms at macro and micro levels in different countries. At the macro level, Sharia supervision could be conducted by national or regional Sharia Supreme Councils and at the micro level, it can be conducted by Sharia Supervisory Board, Sharia Consulting firms or a single Sharia advisor. He concluded that Sharia Supervisory Board is the most common form of supervision adopted in IFIs.

Grassa (2015) in his paper "Shariah supervisory systems in Islamic finance institutions across the OIC member countries - An investigation of regulatory frameworks" reviewed the different practices and regulatory frameworks of Shariah supervision in IFIs across OIC countries. The findings revealed various shortcomings in the shariah supervisory system in most OIC countries which were linked to the regulatory framework, roles and responsibilities of the national Shariah authority and duties and attributes of the institutional Sharia Boards. To bridge these shortcomings, the paper proposed recommendations which were to do with enhancing the monitoring role of national Shariah authorities, improvising existing sharia governance framework particularly regulations in the area of independence of the board, number of board meeting, external sharia review, information disclosure in sharia reports and standardization of different shariah interpretations. 
Hamza (2013) while comparing the decentralized sharia governance model of the Gulf Cooperation Council (GCC) and the centralized sharia governance model of Malaysia, concluded that in decentralized frameworks, it is difficult to achieve consensus in Sharia interpretation and manage properly the existing interest's conflicts, the two principal components of an effective sharia governance structure. The study emphasized the relative robustness of the centralized sharia governance system and cautions against the harmful effects of co-existence of both the systems at the same time leading to regional differences in the application of Islamic finance contracts and credibility of the Islamic industry. In a related study, Grassa (2013) opined that "even though the Southeast Asian sharia governance model looks to be most efficient and effective in achieving the Shariah compliant purpose than the GCC model, it cannot be considered the perfect Shariah supervisory model'.

Hasan (2011) studied the state of Sharia governance practices in Malaysia, GCC countries and the UK in relation to five principle components of a good corporate governance which consist of independence, competency, transparency, disclosure and consistency. A survey questionnaire addressing the following areas - general sharia governance framework, regulatory framework, role of Sharia board, competence of SB, independence, transparency and confidentiality, operational procedures, general assessments of the SB; was administered to 80 IFIs, for which a response rate of $39 \%$ was recorded. The findings revealed significant diversities in sharia governance practices in the sample countries and shortcomings in the governance framework for which suggestions were provided.

An empirical study was undertaken by Hasan (2012) to examine the influence of the dual-layer Sharia governance system existing in Malaysia. The findings of the study while reiterating the significant role of sharia boards and sharia review practices in a dual-governance system, pointed to the laxity through which sharia reviews were implemented by sharia boards, raising concerns about the quality of sharia reports issued by the Boards, thus emphasizing the need for an external sharia audit. Other significant findings of the study included the influence of the sharia board composition on the quality of decisions, influence of integrity, reputation and scholarly background of the sharia board members on accountability and independence.

Wardhany and Arshad (2012) examined the role of sharia board governance structure specifically the responsibilities and authority of sharia board members by comparing the role of sharia board in Indonesia with the role of sharia board in Malaysia and Brunei Darussalam. Findings indicate that role of the Sharia Board in Malaysia and Indonesia do not differ significantly from one another if legislative, business environment conditions and proactive government role are not factored.

Grassa and Matoussi (2014) in their paper on "Corporate governance of Islamic banks: A comparative study between GCC and Southeast Asia countries", compared the governance system in GCC countries and Southeast Asia countries using a sample of 83 Islamic banks across four variable - ownership structure, board of directors, Shariah board and CEO attributes. Their study found significant differences in corporate governance structure of IBs in GCC countries and the Southeast Asia countries. Of particular interest was their findings on the sharia board characteristics between the two sets of countries, which were:

- Shariah board of IBs in Southeast Asian countries were slightly larger than those in the GCC IBs.

- Interlocking membership on the Shariah board is higher in GCC IBs than in Southeast Asian IBs.

- Percentage of scholars with accounting and finance knowledge sitting on the Shariah board of IBs in GCC countries is higher than those in Southeast Asia IBs.

- Shariah boards of IBs in GCC countries meet more frequently than those of Southeast Asia IBs.

- Presence of women in the Shariah boards of Southeast Asia IBs, no woman was observed in the Shariah board of GCC IBs.

- The average fees of Shariah boards are higher in GCC IBs than in those in Southeast Asia IBs.

The authors attributed the several differences in corporate governance characteristics of GCC IBs and Southeast Asia IBs to economic, social and cultural and regulatory factors.

An interesting study by Funds@Work during 2010 raised concerns about multiple board membership and shortage of sharia scholars, through these findings:

- Top 20 Scholars hold 85 to $14 \mathrm{SB}$ membership positions each.

- Top 20 Scholars have 621 SB memberships; the remaining 260 Scholars have 520 SB memberships.

- Top 10 Scholars hold 450 out of 1141 total SB positions and the top 100 have 953 SB positions.

Farook and Farooq (2013) in their paper on "Sharia Governance, Expertise and Profession: Educational Challenges in Islamic Finance", identify significant challenges facing the Islamic finance industry, viz., cost of sharia diligence process, conflict of interest, multiple board membership, sharia scholarship, sharia non-compliance risk and due process. The paper asserts that shortage of qualified sharia scholars is a major challenge that needs to be addressed through institutional, curriculum and certification process.

Garas (2012) undertook an empirical study to identify the relation using OLS between the conflicts of interest in the Sharia Supervisory Board (SSB) in the Islamic financial institutions and six independent variables, which were the SSB executive position, the SSB remuneration, the relation between the SSB members and the Board of Directors (BoD), and the multiple memberships in Islamic funds, issuers of Islamic bonds, and companies trading in capital markets. The findings indicated that four variables (SSB executive position, the relation between the SSB members and the $\mathrm{BoD}$, and the membership in Islamic funds and issuers of Islamic bonds) were significantly related to the conflicts of interest in the SSB.

Nomran et al. (2017) undertook an empirical study to examine whether impact of SSB characteristics on IBs performance could be affected by size effects by using a sample of 25 banks and employing the random-effects GLS and GMM methods. Six SSB characteristics, viz., size, cross-membership, educational qualification, reputation, experience and change in the composition; were employed as explanatory variables, of which four SSB characteristics (size, cross-membership, educational qualification and change in the composition) were found to significantly affect the performance of IBs, when no size difference was factored. The finding varied when sample were re-grouped into subsamples of large and small banks, four SSB characteristics (size, cross-membership, reputation and experience) were found to play an important role in enhancing the performance of large IBs while 
only (reputation and experience) significantly affected the performance of small IBs. This findings confirmed that the impact of SSB characteristics on performance is more for large IBs than small IBs.

The authors also made a contentious conclusion based on the study findings which was that there was lack of sharia governance practices in small IBs in Malaysia and Indonesia.

Mollah et al. (2017) examined whether the difference in governance structures affect the risk-taking and performance of Islamic and conventional banks. Using a sample of 52 Islamic banks and 104 conventional banks across 14 countries, the study concluded that despite cross-country variations and a general perception of a conservative approach to risk taking, it was evidenced that governance structures of Islamic banks facilitate Islamic banks to undertake higher risks and achieve better performance due to product complexities and transaction mechanisms.

Sarea and Mohd (2013) noted in their study that Islamic banks in Bahrain were in full compliance with AAOIFI accounting standards. A similar finding was reported by Hidayat and Al-Khalifa (2018) who observed that Islamic banks in Bahrain practice most aspects of sharia governance outlined in the AAOIFI governance standards.

In conclusion, even though many Islamic countries have in place a Sharia supervisory and governance framework, it has often been commented that these frameworks are inadequate when it comes to addressing the issues and challenges confronting Islamic Banks today (Grassa, 2013; Grassa, 2015; Hidayat and Al-Khalifa, 2018). Researchers (Grais and Pellegrini, 2006; Rammal, 2006; Khan, 2007; Farook and Farooq, 2013; Hamza, 2013; Hassan and Mollah, 2014) have specifically raised issues concerning the workings of Sharia Boards and its membership, viz. shortage of qualified Sharia practitioners, multiple board representation of Sharia Board members, potential conflict of interest, independence of Sharia Board, lack of standardization in Sharia Board rulings and sharia diligence; as some of the major issues and challenges confronting growth of Islamic banks.

In light of the above review, this study seeks to examine the composition and working of the Sharia Boards within locally incorporated Islamic banks in Bahrain.

\section{Research Approach and Methodology}

An exploratory research design was employed in this study due to paucity of primary information in research literature (Hasan, 2011). Based on the suggestion by Creswell (2014) that studies aimed at exploring in detail a central phenomenon could benefit from purposive sampling strategies, this study used purposive sampling procedure, through which five locally incorporated Islamic banks operating in the retail and wholesale segment was shortlisted (as per the CBB's licensed list of locally incorporated Islamic banks, there are six banks who operate in the retail segment).

Given the nature of data requirements, in-depth interview method, specifically expert interview method was initially chosen for which a semi-structured interview schedule was compiled and used to direct the expert interview. In compiling the interview schedule, the following were consulted - AAOIFI Governance Standards for IFIs, No.1, IFSB Guiding Principles on Shariah Governance Systems for Institutions offering Islamic Financial Services, No.10, new Shariah Governance module of CBB (Central Bank of Bahrain) and findings from previous research studies in the area of Shariah governance. Expert interviews were conducted with two individuals, who were instrumental in providing leads for contacting the other three responding banks. Individuals who responded on behalf of the responding Islamic banks included members of the senior management (Vice Chairman, Executive Committee members, CEO and a Senior Management Committee member).

The study made use of descriptive data analysis and content analysis to quantify, analyse and summarize the study findings. Previous research literature and relevant secondary information were accessed using ProQuest and internet

\section{Findings and Discussion \\ 4.1. Profile of Respondents}

Total assets for the five banks surveyed ranged from BD 75 million to BD 1589 million; with two banks (40\%) in the 'above BD 1000 million' category and equal representation from the remaining banks in the 'less than BD 100 million' (20\%), between 'BD 100 to 500 million' (20\%) and between 'BD 500 to 1000 million' asset categories. All the five banks surveyed were locally (Bahrain) incorporated Islamic banks operating in the retail $(60 \%)$ and wholesale $(40 \%)$ segment. Individuals who responded on behalf of their banks were members of the senior management, which included Vice Chairman (20\%), Executive Committee member (40\%), CEO (20\%) and Senior Management Committee member (20\%).

In line with $\mathrm{CBB}$ directives and AAOIFI requirements, all surveyed banks (100\%) reported to have established a Sharia Supervisory Board (SSB), the membership of which ranged from 3 members to 5 members. All surveyed banks complied with the minimum membership requirement which is 3 scholars.

Of the 18 members (includes 2 members with cross-membership in two banks) who made up the SSB across the five surveyed banks, $75 \%$ (12 of 16) hold a Ph.D. of which, $83 \%$ was in Islamic jurisprudence and $17 \%$ in Islamic finance or economics; 2 hold a masters and a bachelor degree in Islamic sharia / Arabic literature and the remaining 2 hold a bachelors in economics / Islamic jurisprudence. In terms of nationality of SSB members, 38\% (6 of 16) are Bahrainis and the remaining (62\%) non-Bahrainis, from Saudi Arabia, Kuwait, Egypt, Yemen, Algeria and Pakistan. Most of the SSB members hold multiple-SSB membership in regional and international Islamic financial institutions with 3 members associated in the capacity of SSB Chairman or SSB member in more than 10 IFIs; 5 members associated in the capacity of SSB member in 5 to 10 IFIs and the remaining (50\% of the members) with multiple-SSB membership ranging between 2 and 4. Further, all sharia board members in the surveyed Islamic banks were male, supporting the findings of Hasan (2011) that sharia boards in GCC and UK are male domains. Most of the SSB members of surveyed banks have a stellar track record in terms of their qualification (scholars in fiqh-al-muamalat), experience, exposure, recognition and contribution to the Islamic financial industry; thus fulfilling the AAOIFI, IFSB and CBB requirements and guidelines of appointing a reputable and credible sharia board, with at-least three members, trained in various schools of Islamic jurisprudence comprising of different nationalities and with varied experience. 
All $(100 \%)$ the surveyed banks reported to have in place a charter / terms of reference, which defines the scope of work for the SSB. There was agreement among the surveyed banks on the nature of issues stated in the charter, which includes - constitution, composition, appointment and replacement of SSBs and members; duties, responsibilities and authority of SSBs, reporting and relationship structure of SSBs. Again this finding is hardly surprising given the AAOIFI, IFSB and CBB requirements and guidelines in this regard.

To the question as to how many meetings of the SSB were convened during the last financial year and on an average how many of these meetings were attended by each SSB member, two banks reported to have convened 3 to 4 meetings of the SSB with attendance of $100 \%$ while 3 banks reported to have held between 5 and 6 meetings, with attendance of $75 \%$. As per the new $\mathrm{CBB}$ regulations, SSBs have to meet at-least once on a quarterly basis and each SSB member must attend at-least three-fourths of the meetings during a calendar year to review and approve decisions relating to Sharia matters.

Most (80\%) of the surveyed banks report to offer a contract for appointment to the SSB for a minimum period of 3 years \& beyond with one bank stating the same to be one year. None (100\%) of the banks reported to the existence of mandatory rotation in SSB membership. Further, it is also found that banks don't report the benefits and remuneration offered to SSB members to general assembly, which is a requirement as per the new CBB regulation $\mathrm{SG}$ 2.4.2.

Surveyed Banks were asked to rate on a scale of 1 to 4 a list of 9 fitness assessment criteria' for individuals to serve on the SSB. None of the 9 items received either a 'low' or 'not valued' rating. Responses ranged between 'high' and 'moderate' for all the 9 items. The following two items received the highest modal score of $4-$ "possession of a bachelor degree in Islamic Sharia" and "strong proficiency in Arabic". These findings are in line with the requirements of CBB (SG 2.4.4) and IFSB guidelines (2.1) which suggest that an Islamic bank must conduct a background check to verify that any person appointed as a SSB members should satisfy the following three competencies - academic qualification (holding at-least a bachelor degree in sharia including fiqh almuamalat), experience and exposure (experience in applying Sharia to a bank's proposed activities, awareness of applicable general legal and regulatory framework, experience of making sharia pronouncement) and track record (respectable character and conduct).

To the question whether the bank offers any induction / training programs for SSB members in the areas of Islamic finance and accounting, 3 banks (60\%) stated they sponsor their SSB members for ongoing seminars \& conferences as part of their professional development. With the new CBB directive SG2.6.2, it is necessary for Islamic banks to offer appropriate induction and training programs for their SSB members. This finding is more or less in line with a similar finding reported by Hasan (2011) that slightly less than 60 percent of IFIs provided professional training especially in the matters of finance and banking to their Sharia board.

To the question whether the bank assesses effectiveness of SSB and its members, all surveyed banks reported to assess the SSB as a whole and contribution of each member on an annual basis, with $40 \%$ stating they do it "to a great extent" and the other $60 \%$ stating they do it "to some extent".

This finding is in line with the guidelines of IFSB and CBB new directive (SG-2.7.1 \& 2), which suggests that IBs should specify and adopt a process for assessing the effectiveness of the SSB and contribution of each member. This finding is also an improvement to a finding by Hasan (2011) who concluded that a significant number of IFIs don't evaluate or assess the performance of their Sharia board.

A further related question on 'do you use the results of this assessment for considering re-nomination and seeking resignation of SSB members' produced contrasting response, where 3 banks (60\%) stated they use the performance evaluation for making key decisions "to some extent" and 1 bank reported to use the evaluation "to a great extent" and one bank reporting to "not using it at all".

With respect to having standard operating procedures (SOPs) for holding and recording of SSB meetings and decision making process, all surveyed banks (100\%) reported to have SOPs in the following areas - request submission, holding and recording of SSB meetings, decision-making and review process of the SSB. However, 2 banks reported these SOPs to be not very detailed. Further, all the surveyed banks (100\%) reported to have in place a code of ethics and conduct for their SSB members, which is marked improvement over a related finding by Hasan (2011) which indicated that $26 \%$ of Sharia boards are not guided by a code of ethics.

Surveyed Banks were asked to rate on a scale of 1 to 4 , the extent to which stakeholders have access to information regarding SSB duties, decision making process, composition, competence and fatwas \& reports issued by SSB. Modal scores for the given responses ranged from 'seldom' (for Decision making process of the SSB) to 'most of the time' (for Composition of SSB). Information on duties of SSB, competence of SSB members, publication of all fatwas / rulings / guidelines / reports issued by SSB were provided 'some of the time'.

To understand the extent to which the often quoted concerns raised in research literature about composition and workings of the SSBs, Banks were asked whether a list of concerns presented to them posed a challenge and if so how were they managing them.

- Shortage of qualified sharia practitioners in Fiqh al Muamalat - There was a unanimous opinion that there was indeed a shortage of qualified sharia practitioners, particularly in the area of Fiqh al Muamalat. Banks reported to managing this challenge by nominating non-Bahraini to SSB boards.

- Sharia practitioners of different schools of thought - Opinions were divided among banks when asked to what extent they believe Sharia practitioners of different schools of thought pose a challenge. Two banks considered it a challenge while the other three opined that this diversity enriched the decision and thought process which is mutually beneficial for the industry and consumers.

- Level of familiarity of Sharia practitioners with modern day banking services and sharia audit is limited - There was a more or less a consensus among Banks that most of the sharia practitioners on SSB are familiar with modern day banking services and audit requirements.

- Multiple board representation of Sharia Board members - While conceding that multiple board representation of SSB members is a challenge, almost all Banks were of the opinion that this doesn't pose a problem to Banks as long as there is no conflict of interest. Formation of a central sharia bureau was one of the suggestion put forth for dealing with this challenge. 
- Lack of standardization in Sharia ruling (fatwa) - There was a general agreement that lack of standardization in fatwa rulings was one of the challenges in Islamic banking. However, there was references to how the industry was moving towards standardization through the involvement of CBB and AAOIFI.

\section{Conclusion and Direction for Further Research}

In conclusion it can be said that Islamic banks in Bahrain, in line with AAOIFI requirements, IFSB guidelines and CBB's new SG module; have in place a sharia governance structure through a Sharia Supervisory Board, with clear terms of reference, operating procedures and a code of professional conduct thus supporting the findings of similar studies (Sarea and Mohd, 2013; Hidayat and Al-Khalifa, 2018) in this regard. However, there still seems to be lack and/or inconsistency in practices among banks concerning reporting of benefits and remuneration offered to SSB members, offering appropriate induction and training programs for SSB members and disclosing information on decision making process of SSB and publication of fatwas / reports issued by SSBs. Concerns raised by previous research on shortage of qualified Sharia practitioners, multiple board representation of Sharia Board members, potential conflict of interest, independence of Sharia Board, lack of standardization in Sharia Board rulings and sharia diligence; continue to be considered contemporary challenges, however it is noteworthy that Islamic banks in Bahrain have devised appropriate risk management strategies to deal with some of these issues.

Even though the current findings could be generalized for the Islamic banking sector in Bahrain, future research with larger samples or complete enumeration methodologies could look into scale and segment effect in sharia governance practices among Islamic banks. Further, this study didn't explore the role and activities of the internal sharia unit and the nature of symbiotic relations with the SSB, which can be further explored.

\section{References}

Alman, M., 2012. shari'ah supervisory board composition effects on Islamic banks' risk-taking behavior. Journal of Banking Regulation, 14(1): 134-163.

Aziz, A., 2012. Sharia governance: Challenges ahead. MPRA Paper No 4772, 14-15. Available from https://mpra.ub.unimuenchen.de/47772/1/MPRA_paper_47772.pdf.

Bahrain, E., 2017. Bahrain for Islamic finance. Available from http://bahrainedb.com/app/uploads/2017/06/IslamicFinance-254x179Insert-Jun2017.pdf.

Creswell, J.W., 2014. Research design: Qualitative, quantitative, and mixed methods approaches. 4th Edn., Thousand Oaks, CA: Sage.

Farook, S. and M.O. Farooq, 2013. Shariah governance, expertise and profession: Educational challenges in Islamic finance. ISRA International Journal of Islamic Finance, 5(1): 137-160.Available at: https://doi.org/10.12816/0002761.

Garas, N.S., 2012. The conflicts of interest inside the Shari'a supervisory board. International Journal of Islamic and Middle Eastern Finance and Management, 5(2): 88-105.Available at: https://doi.org/10.1108/17538391211233399.

Garas, S. and C. Pierce, 2010. Shari'a supervision of Islamic financial institutions. Journal of Financial Regulation and Compliance, 18(4): 386-407.Available at: http://doi.org/10.1108/13581981011093695.

GIFR, 2017. Overview of the global islamic finance industry. The Global Islamic Finance Report. Available from http://www.gifr.net/publications/gifr2017/intro.pdf.

Grais, W. and M. Pellegrini, 2006. Corporate governance and Shariah compliance in institutions offering Islamic financial services (World Bank Policy Research WP No. 4054).

Grassa, R., 2013. Shariah supervisory system in Islamic financial institutions: New issues and challenges: A comparative analysis between Southeast Asia models and GCC models. Humanomics, 29(4): 333-348.Available at: https://doi.org/10.1 108/h-01-2013-0001.

Grassa, R., 2015. Shariah supervisory systems in Islamic finance institutions across the OIC member countries: An investigation of regulatory frameworks. Journal of Financial Regulation and Compliance, 23(2): 135-160.Available at: https://doi.org/10.1108/jfrc-02-2014-0011.

Grassa, R. and H. Matoussi, 2014. Corporate governance of Islamic banks: A comparative study between GCC and Southeast Asia countries. International Journal of Islamic and Middle Eastern Finance and Management, 7(3): 346-362.Available at: https://doi.org/10.1108/imefm-01-2013-0001.

Hamza, H., 2013. Sharia governance in Islamic banks: Effectiveness and supervision model. International Journal of Islamic and Middle Eastern Finance and Management, 6(3): 226-237.Available at: https://doi.org/10.1 108/imefm-02-2013-0021.

Hasan, A.F., 2012. An empirical investigation into the role, independence and effectiveness of Shari'ah boards in the Malaysian Islamic banking industry (Doctoral dissertation, Cardiff University).

Hasan, Z., 2011. A survey on Shari'ah governance practices in Malaysia, GCC countries and the UK: Critical appraisal. International Journal of Islamic and Middle Eastern Finance and Management, 4(1): 30-5 1.Available at: https://doi.org/10.1108/17538391111122195.

Hassan, M.K. and S. Mollah, 2014. Corporate governance, risk-taking and firm performance of Islamic banks during global financial crisis (Working Paper).

Hidayat, S.E. and A.K. Al-Khalifa, 2018. Shariah governance practices at Islamic banks in Bahrain from Islamic bankers' perspective. AlIqtishad Journal of Islamic Economics, 10(1): 53-74.Available at: https://doi.org/10.15408/aiq.v10i1.5991.

ICD Thomson Reuters, 2017. ICD-Thomson Reuters Islamic Finance Development Report 2017. Available from https://islamicbankers.files.wordpress.com/2017/12/icd-thomson-reuters-islamic-finance-development-report-2017.pdf.

IFSB, 2009. Guiding principles of Shariah governance systems for institutions offering Islamic financial services. Available from https://ifsb.org/standard/IFSB-10\%20Shariah\%20Governance.pdf.

Imam, P. and K. Kpodar, 2010. Islamic banking: How has it diffused? (IMF Working Paper, WP/10/195, 1-18).

Khan, M.F., 2007. Setting standards for Shariah application in the Islamic financial industry. Thunderbird International Business Review, 49(3): 285-307.Available at: https://doi.org/10.1002/tie.20145.

Mejia, A., S. Aljabrin, R. Awad, M. Norat and W. Song, 2014. Regulation and supervision of Islamic banks. IMF Working Paper No. WP/14/219. Washington: International Monetary Fund. Available from: http://dx.doi.org/10.5089/9781498361590.001.

Mizushima, T., 2014. Corporate governance and Shariah governance at Islamic financial institutions: Assessing from current practice in Malaysia. Reitaku Journal of Interdisciplinary Studies, 22(1): 59-84

Mollah, S., M.K. Hassan, O. Al Farooque and A. Mobarek, 2017. The governance, risk-taking, and performance of Islamic banks. Journal of Financial Services Research, $51(2): 195-219$.

Nomran, N.M., R. Haron and R. Hassan, 2017. Bank performance and Shari'ah supervisory board attributes on Islamic banks: Does bank size matter? Journal of Islamic Finance, 6(Special Issue): 174-187.Available at: https://doi.org/10.12816/0047348.

Rammal, H.G., 2006. The importance of Shari'ah supervision in Islamic financial institutions. Corporate Ownership and Control, 3(3): 204208.Available at: https://doi.org/10.22495/cocv3i3c1p5.

Sarea, A.M. and H.M. Mohd, 2013. Adoption of AAOIFI accounting standards by Islamic banks of Bahrain. Journal of Financial Reporting \& Accounting, 11(2): 131-142.Available at: https://doi.org/10.1108/jfra-07-2012-0031.

Wardhany, N. and S. Arshad, 2012. The role of Shariah board in Islamic banks: A casestudy of Malaysia, Indonesia and Brunei Darussalam. Paper Pesented at 2nd ISRA Colloqium 2012 on Islamic Finance in a Challenging Economy: Moving Forwar, pp: 1-22. 